\title{
An overview of microtubule targeting agents for cancer therapy
}

\author{
Bensu Karahali1 ${ }^{1}$, Sevgi Yardım-Akaydin², and Sultan Nacak Baytas ${ }^{3}$ \\ ${ }^{1}$ Department of Toxicology, Faculty of Pharmacy, Gazi University, Ankara, Turkey \\ ${ }^{2}$ Department of Biochemistry, Faculty of Pharmacy, Gazi University, Ankara, Turkey \\ ${ }^{3}$ Department of Pharmaceutical Chemistry, Faculty of Pharmacy, Gazi University, Ankara, Turkey
}

[Received in January 2019; Similarity Check in January 2019; Accepted in September 2019]

The entire world is looking for effective cancer therapies whose benefits would outweigh their toxicity. One way to reduce resistance to chemotherapy and its adverse effects is the so called targeted therapy, which targets specific molecules ("molecular targets") that play a critical role in cancer growth, progression, and metastasis. One such specific target are microtubules. In this review we address the current knowledge about microtubule-targeting agents or drugs (MTAs/MTDs) used in cancer therapy from their synthesis to toxicities. Synthetic and natural MTAs exhibit antitumor activity, and preclinical and clinical studies have shown that their anticancer effectiveness is higher than that of traditional drug therapies. Furthermore, MTAs involve a lower risk of adverse effects such as neurotoxicity and haemotoxicity. Several new generation MTAs are currently being evaluated for clinical use. This review brings updated information on the benefits of MTAs, therapeutic approaches, advantages, and challenges in their research.

KEY WORDS: chemotherapy; MDA; microtubule stabilising agents; microtubule destabilising agents; MSA; MTA

\section{Abbreviations}

CA-4 - combretastatin A-4; CA-4P - CA-4 phosphate; FDA - Food and Drug Administration; GDP - guanosine diphosphate; GC-MS- Gas Chromatography-Mass Spectrometry; GTP - guanosine triphosphate; HER2 human epidermal growth factor receptor 2 ; $\mathrm{IC}_{50}-$ halfmaximal inhibitory concentration; MDA - microtubuledestabilising agent; METHF - 5-methyltetrahydrofolate; MSA - microtubule-stabilising agent; MTA/MTD microtubule-targeting agent/drug; NCI - National Cancer Institute; NIH - National Institutes of Health; NKCC1 Na-K-Cl cotransporter; NLM - National Library of Medicine; NMR - nuclear magnetic resonance; NPACT - naturally occurring plant-based anti-cancer compoundactivity target; $\mathrm{PN}$ - peripheral neuropathy

Cancer is a multifactorial disease that invades adjoining parts of the body and spreads to other organs (1). Cancer cells lack normal genetic regulation and often have mutations in one or more mitotic checkpoints or mitotic errors which are not properly detected/repaired due to mutations in the cellular machinery (2).

The aim of common cancer therapies (chemotherapy, radiation therapy, or surgery) is to effectively destroy cancer cells without harming normal cells or tissues (3). Among

Corresponding author: Professor Bensu Karahalil, Gazi University, Faculty of Pharmacy, Toxicology Department, Ankara, Turkey

E-mail:bensu@gazi.edu.tr orbensuka@gmail.com them, chemotherapy has been the most common -ever since the 1940 s, when the first widely used cancer drug, called nitrogen/sulphur mustard, was discovered. However, chemotherapeutic agents have undesirable adverse effects, as they cannot distinguish between normal and cancer cells.

The idea behind targeted therapy is to minimise the adverse effects by targeting parts of cancer cells that distinguish cancer from normal.

This review focuses on one such targeted therapy with microtubule-targeting agents (MTAs), first introduced into clinical use in the late 1950s. Fundamentally, MTAs induce mitotic arrest through interference with intracellular transport and suppression of microtubule dynamics, resulting in cytotoxicity (4).

\section{FUNCTIONS OF MICROTUBULES}

Microtubules are involved in a number of cellular processes, such as the maintenance of cell shape, division, and migration, intracellular transport, and endothelial cell biology (5). They play a crucial role in the assembly of the spindle apparatus and right segregation of chromosome $(6,7)$.

Their crucial involvement in the formation of mitotic spindles during cell division makes them an attractive target for cancer therapy. 


\section{MECHANISMS OF ACTION OF MTAs}

MTAs act against mitosis by interacting with tubulins at different sites (Figure 1) (6) and interfering with the spindle dynamics. According to the mechanism of action, they are traditionally divided in two major groups: microtubule-stabilising (MSAs) and microtubule destabilising agents (MDAs). MSAs, such as taxanes (8), epothilones (9), and laulimalide (10) promote and stabilise tubulin polymerisation, whereas MDAs do the opposite. They prevent tubulin polymerisation and promote depolymerisation. Disassembly promoters bind to either the colchicine domain at the intradimer interface between $\alpha$ - and $\beta$-tubulin or the vinca domain near the exchangeable GTP-binding site (E-site) on $\beta$-tubulin (11). This group includes colchicines (12), vinca alkaloids (13), eribulin, nocodazole (14), and combretastatin A-4 (CA-4) $(11,15)$.

Regardless of different binding sites, most MTAs elicit remarkably similar effects on microtubules, especially at the lowest effective drug concentrations. Taxanes bind to polymerised microtubules at the inner surface of the $\beta$ subunit and stimulate tubulin polymerisation (8). Similarly, epothilones bind to the taxane pocket of $\beta$-tubulin (16). Colchicine, in turn, binds tubulin and blocks polymerisation (12). Vinca alkaloids (vinblastine, vincristine) cause depolymerisation by forming tubulin paracrystals (6). Laulimalide and peloruside also bind to a non-taxane site between two $\beta$-tubulins and promote the assembly of microtubules $(17,18)$ by strongly modulating longitudinal interactions between tubulin dimers and moderately modulating lateral interactions (2). Eribulin inhibits tubulin polymerisation by binding the interdimer interface or the $\beta$-tubulin subunit. It also sequesters tubulin monomers into non-functional aggregates (13). Nocodazole interferes with the polymerisation of microtubules (14).

\section{STUDIES ON MTAs: FROM MOLECULE TO DRUG}

Small organic molecules which disrupt microtubule/ tubulin dynamics have been used in cancer therapy for many years, and new small organic molecules with antitubulin activity are being studied and developed (19).

\section{Combretastatin A-4 derivatives}

Combretastatin is a natural product isolated from Combretum caffeum grown in South Africa. CA-4 and its analogues (Figures 2 and 3 ) are potent antitumour agents with demonstrated biological activity (20-23). CA-4 has low water solubility, but this problem has been solved with water-soluble derivatives. Recent studies (24) report that CA-4 causes 90-99 \% tumour necrosis, and phase III clinical trials with CA-4 evidence that CA-4P is effective and safe in the treatment of thyroid cancer (25).

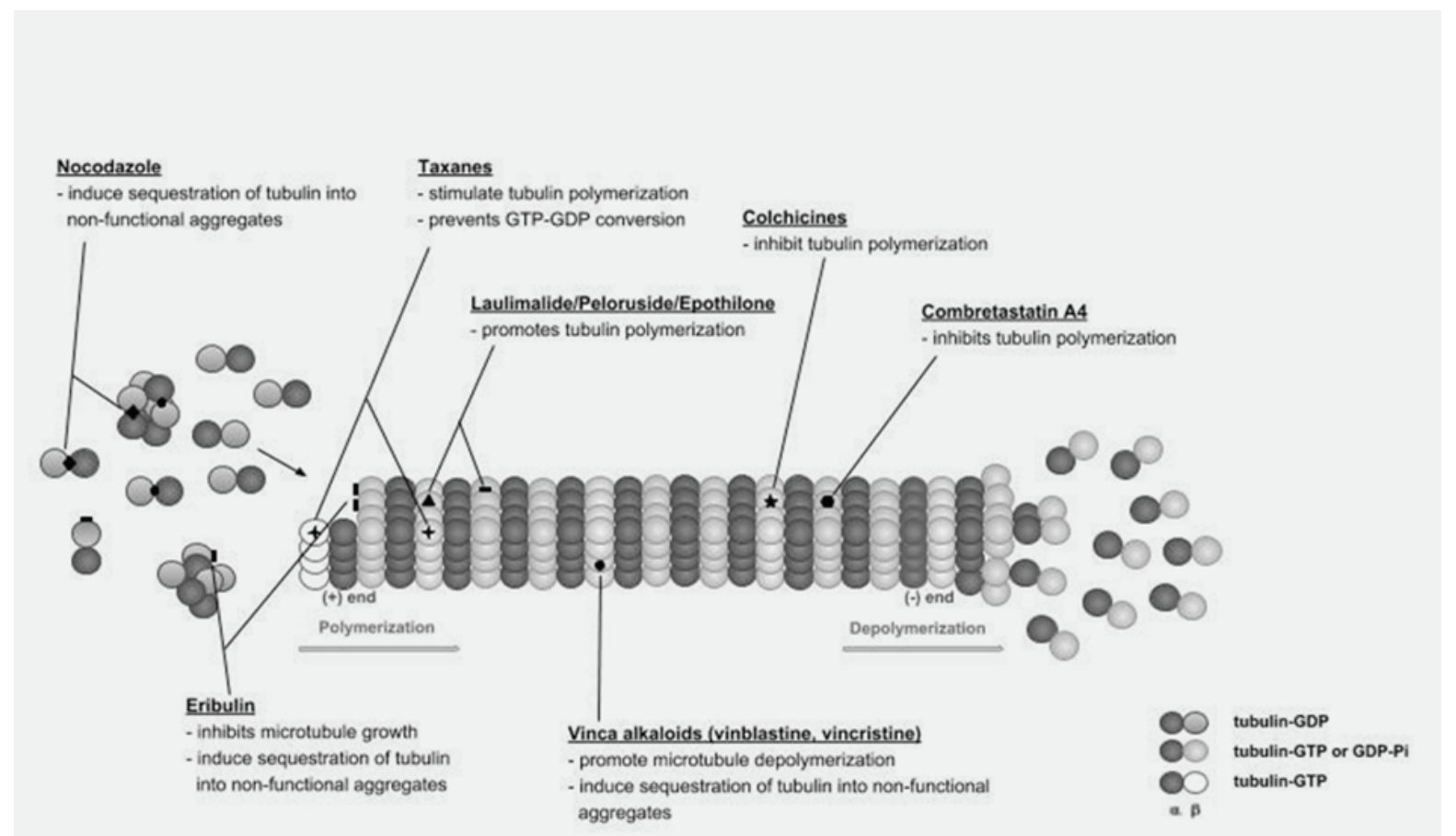

Figure 1 Inhibition of microtubule polymerisation and depolymerisation by MTAs. + Taxanes bind to inner surface and plus ends of microtubule; $\$$ Colchicines bind to $\beta$-tubulin in the outer surface of the microtubule; $\mathbf{Q V i n c a}$ alkaloids bind to $\beta$-tubulin in the outer surface of the microtubule and to tubulin dimers; $\diamond$ Nocodazole binds to tubulin dimers; Eribulin binds to $\beta$-tubulin in the microtubule end and to tubulin dimers; $\boldsymbol{\Delta}$ Laulimalide and peloruside bind to $\beta$-tubulin in the outer surface of the microtubule (laulimalide binding site); Epothilone binds to $\beta$-tubulin in the outer surface of the microtubule (near the taxane-binding site); Combretastatin A4 binds to the colchicine-binding site 


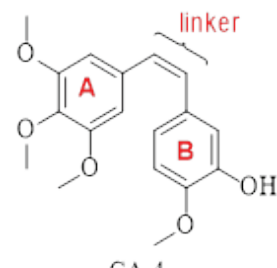

CA-4

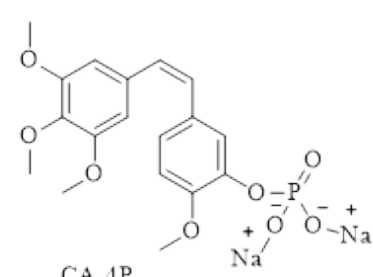

CA- $4 \mathrm{P}$
Figure 2 CA-4 (with pharmacophore groups) and CA-4P structure

\section{Colchicine derivatives}

Colchicine is obtained from Colchicum autumnale by extraction. It strongly binds to tubulin and disturbs microtubule assembly dynamics. Due to its toxicity, research has been focused on less toxic colchicine derivatives (Figure 4) $(26,27)$.

\section{Indole derivatives}

In recent years, a number of pharmacological activity studies have been focused on compounds bearing indole structure and reported antitumour activity through inhibition of tubulin polymerisation. Indole has also provided one of the most important skeletons for CA-4 analogues (28-32). Figure 5 shows some examples of MTAs with indole backbone (compounds 12-18) (33-39).

\section{Other MTAs}

Heterocyclic compounds such as 5-flourouracil, methotrexate, doxorubicin, and daunorubicin exhibit anticancer properties and have always made the core of anticancer drugs (40).

Flavonoids and isoflavonoids are natural oxygen heterocyclic compounds carrying a benzopyran-4-one building block. The biological activity of flavonoids and isoflavonoids changes with the position of the phenyl ring. Flavonoids have the benzopyran-4-one core with a phenyl ring at position 2, and isoflavonoids at position 3 . Flavonoids with anticancer activity include baicalein and quercetin, which have a 2-arylbenzopyran-4-one pharmacophore group. Tambulin (3,5-dihydroxy-7,8dimethoxy-2-(4-methoxyphenyl)benzopyran-4-one) is isolated from the fruits of Zanthoxylum armatum and used as a starting material for the synthesis of alkyl amine derivatives (Figure 6, compound 19) (41).

Shikonin is isolated from the root of Lithospermum erythrorhizon and has been used in Europe and Asia since antiquity (42). This natural compound has many pharmacological properties, such as wound healing, antioxidant, antibacterial, anti-inflammatory, and antitumour (43-47). Structural changes have been made to increase target specificity, since shikonin shows non-selective cytotoxic effects on normal cells. One such compound is chalcone-containing shikonin derivative (48) (Figure 6, compound 20).

ABT-751 (Figure 6, compound 21) is an oral synthetic antimitotic sulphonamide. It binds to the colchicine-binding site on $\beta$-tubulin and inhibits the polymerisation of microtubules. This, in turn, stops the cell cycle at the G2/M

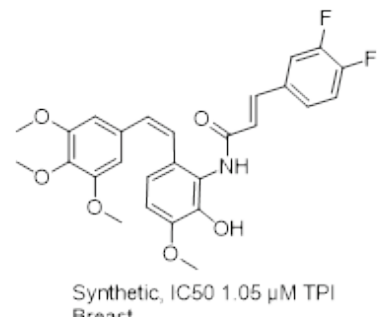

Synthetic,
Breast

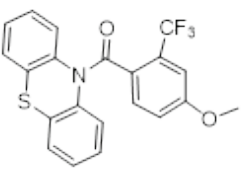

Synthetic, IC50 11.9 $\mu \mathrm{M}$ TPI Breast, lymphoblastic leukemia 3

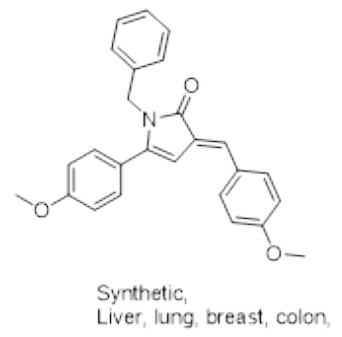

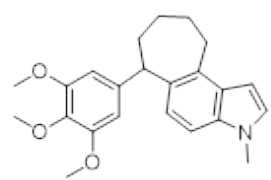

Synthetic, IC50 0.15 $\mu \mathrm{M}$ TPI

Lung, liver, prostate, breast, ovarian, colon
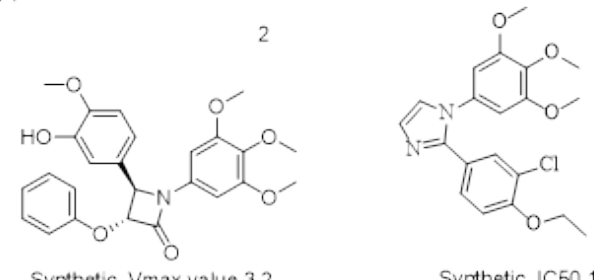

Synthetic, Vmax value 32

breast cancer

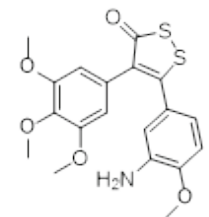

Synthetic, IC50 $4.44 \mu \mathrm{M}$ TPI Gastric, oral squamous epithelium, fibrosarcoma

Synthetic, IC50 $11.9 \mu \mathrm{M}$ TPI Cervical, lung colon breast

5

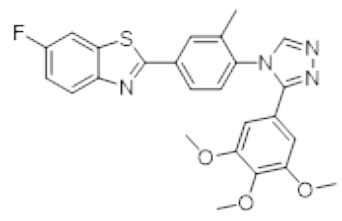

Synthetic, IC50 $1.00 \mu \mathrm{M}$ TPI Lung

Figure 3 Some of the novel CA-4 analogues; TPI - tubulin polymerisation inhibition 
<smiles>[R]C(=O)NC1CCc2cc(OC)c(OC)c(OC)c2-c2ccc(OC)c(=O)cc21</smiles>

Semisynthetic, IC50 0.70 $\mu \mathrm{M}$ TP Colon, breast

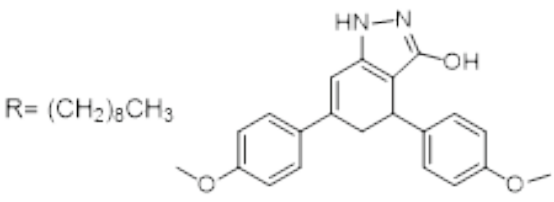

Synthetic. $86 \%$ inhibition in HCT-116 cells Colon, breast

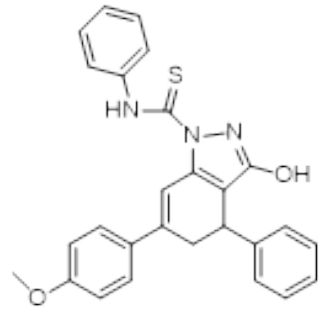

Synthetic. $89 \%$ inhibition in HCT-116 cells Colon, breast

10

11

Figure 4 Small molecules derived from colchicine<smiles>COc1cc(/C=C/C(=O)/C=C/c2c[nH]c3ccccc23)cc(OC)c1OC</smiles>

Synthetic, IC50 $8.83 \mu \mathrm{M}$ TP| Prostate<smiles>COc1cc(C2=NN(C(N)=O)C(c3cn(C)c4ccc(Br)cc34)C2)cc(OC)c1OC</smiles>

Synthetic, IC50 $2.12 \mu \mathrm{M}$ TPI Liver, breast, lung

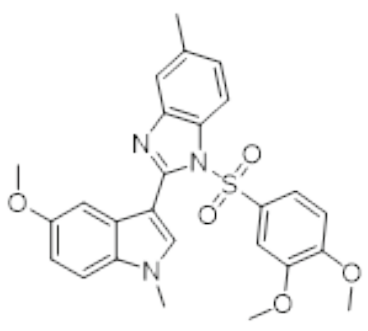

Syrthetic, IC50 1.41 $\mu \mathrm{M}$ TP Liver, breast, lung<smiles>Cn1cc(C(=O)C(=O)N2CCCCC2)c2cc(Nc3nccc(-c4ccc(Cl)cc4)n3)ccc21</smiles>

Synthetic IC50 0.40 $\mu \mathrm{M}$ TP Prostate, lung, colon

15<smiles>NC(=O)Cc1ccc(OCc2ccccc2)cc1</smiles><smiles>Cc1c(CC(=O)NCCN(C)C)c2ccccc2n1C(=O)c1ccc(Br)cc1</smiles>

Synthetic

Lung, colon, breast, prostate

16<smiles>COc1cc(NC(=O)/C=C/c2c[nH]c3ccccc23)cc(OC)c1OC</smiles>

Synthetic, IC50 $17 \mu \mathrm{M}$ TPI Breast, Burkitt lymphoma, promyeloctic leukemia, cervical

17<smiles>O=C(c1ccc2c(c1)Sc1ccccc1N2)c1c[nH]c2ccccc12</smiles>

Synthetic, IC50 $38.9 \mu \mathrm{M}$ TPI Breast, lymphoblastic leukemia

Figure 5 Some recent compounds with an indole backbone structure

phase and cellular apoptosis and prevents tumour cell replication. ABT-751 has been evidenced a significant anticancer effect against non-small cell lung cancer (NSCLC) and colon cancer (49-52). Elmeligie et al. (53) synthesised a series of new 3-substituted-2-(4hydroxyanilino) pyridine derivatives structurally related to ABT-751. They evaluated their cytotoxicity using inhibitory activity of tubulin polymerase (Figure 6). 4-[3-[5-(4-methoxyphenylamino)-1,3,4-oxadiazol-2-yl] pyridin-2-ylamino] phenol (compound 22) also showed high inhibitory activity.

Moving from the structure of ABT-751, Liu et al. (54) synthesised 7-substituted 1-methyl-1,4- dihydroindeno[1,2-c] pyrazole (compound 23) as a potential tubulin polymerisation inhibitor by targeting a new binding region at the interface between $\alpha$ and $\beta$-tubulin heterodimers at the colchicine binding site. Pyrazole aldehydes (4a-d), Knoevenagel's condensates (5a-d), and Schiff's bases (6ad) of curcumin-I were also synthesised, and analysed for haemolysis, cell line activities, DNA binding and docking. These compounds were less haemolytic than standard drug doxorubicin (55).

Metal-based drugs such as cisplatin have commonly been used in cancer therapy. However, due to severe toxicity of platinum drugs, research focus has shifted to the synthesis of new, less toxic drugs. An example is pyrazoline-based 


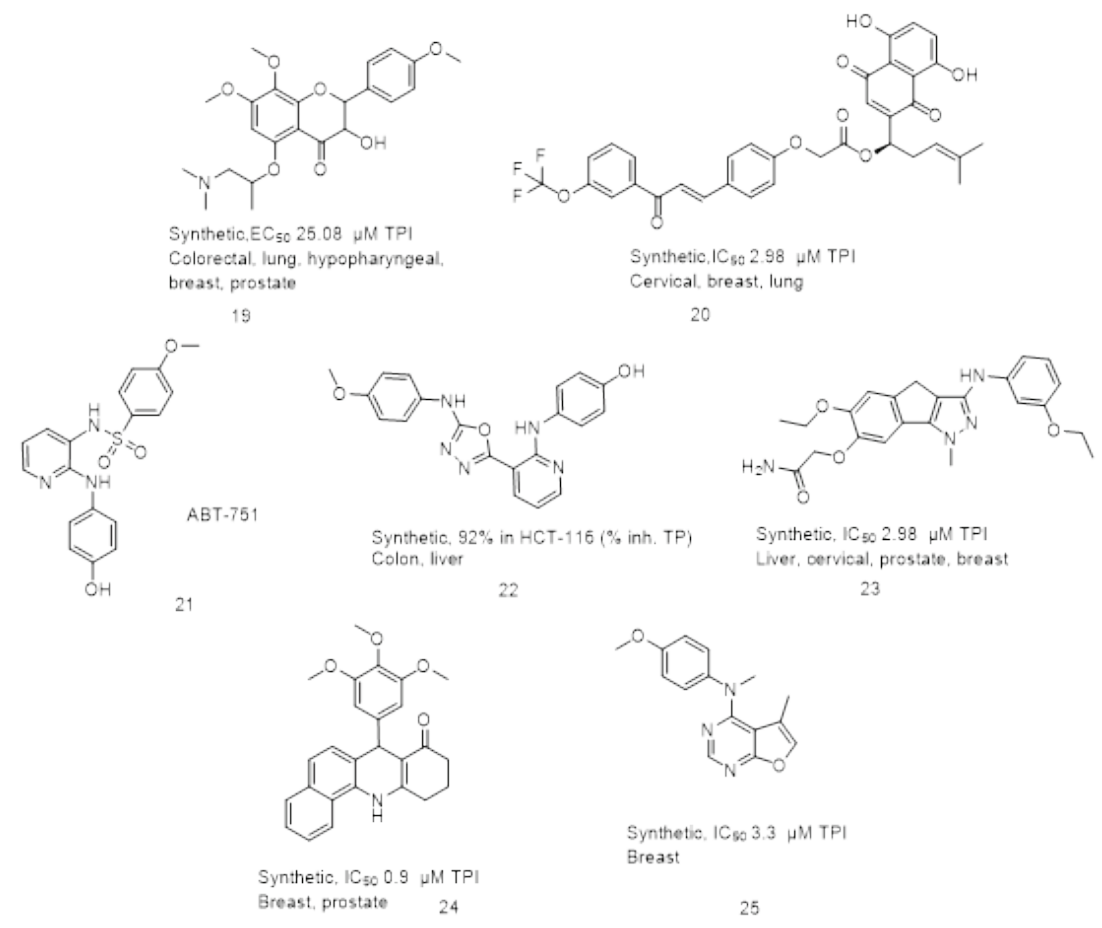

Figure 6 Miscellaneous derivatives synthesised and evaluated as MTAs

ligand [5-(4-chlorophenyl)-3-(4-fluorophenyl)-4,5-dihydro1H-pyrazole-1-carbothioamide] and its complexes with copper(II), nickel(II), and iron(III) metal ions. In silico and DNA binding studies suggest that these agents have good DNA binding ability, which is an important prerequisite for effective anticancer drugs (56).

Magalhase et al. (57) designed and synthesised acridin8-one derivatives (compound 24), inspired by the structure of podophyllotoxin. Podophyllotoxins are natural agents which bind to the colchicine-binding site with remarkable inhibitory activity on microtubule assembly.

There are also reports of the design, synthesis, and biological evaluations of novel 4-substituted 5-methylfuro[2,3-d] pyrimidines (58). Compound 25 (Figure 6) is an important candidate for further research and development. It is currently under preclinical evaluations.

\section{NATURAL COMPOUNDS}

Taxol, a taxanediterpenoid, is widely used in the treatment of a variety of cancers (breast, ovarian, lung, head, and neck) $(5,60)$. Taxanes promote tubulin stabilisation by straightening GDP-tubulin protofilaments into a conformation resembling GTP-tubulin $(61,62)$.

So far, more than 400 taxanes have been isolated from several Taxus species (63), including $N$-debenzoyl- $N$ methyl- $N$-heptanoyl-taxol (compound 26), $N$-debenzoyl$N$-methyl- $N$-octanoyl-taxol (compound 27), $N$-debenzoyl$\mathrm{N}$-methyl- $N$-(4-methylhexanoyl)-axol (compound 28), and $N$-debenzoyl- $N$-methyl- $N$-[(4Z)-1-oxo-4-tenenoyl] taxol (compound 29) (Figure 7) identified in Taxus wallichiana var. mairer (64). Their antitumor activities were evaluated in different cancer lines (MCF-7, A549, and 3-AO). Compound 28 showed a significant antitumor activity on the MCF-7 cell line, with anticancer effect similar to taxol, which was used as positive control. In fact, compound 28 has been reported as a promising anticancer agent in breast cancer therapy. Compounds 26, 27, and 29 showed lower cytotoxicity than paclitaxel. All of them also exhibited a change/shift in microtubule dynamics similar to that of paclitaxel.

The microtubule cytoskeleton is the main target of paclitaxel (65). This drug interacts with the $\beta$-subunit of polymerised microtubules and prevents their depolymerisation, which, in turn, results in mitotic arrest and apoptosis. Verma et al. (66) tried to identify a potent $\beta$-tubulin inhibitor using experimental and in silico approaches. For this purpose, compounds were extracted from Cassia fistula and their structure identified by GC-MS. Subsequently, oral bioavailability, toxicity, and docking studies resulted in one promising inhibitor molecule, namely Hop-22(29)-en-3. beta-ol (Figure 8). The results of in silico studies suggest that it binds effectively to both the native and mutant $\beta$-tubulin. Its bioavailability was significantly higher than that of paclitaxel. However, these results need confirmation from experimental findings.

Searching the Naturally Occurring Plant-based Anticancer Compound-Activity-Target (NPACT) database, Verma et al. (66) identified 1574 alkaloids with anticancer potential. Their pharmacokinetics and toxicity, binding efficiency, binding affinity of the docked complex, and metabolising capacity were evaluated by several computer programs. The results of these computational analyses suggest, for the first time, that isostrychnine isolated from 


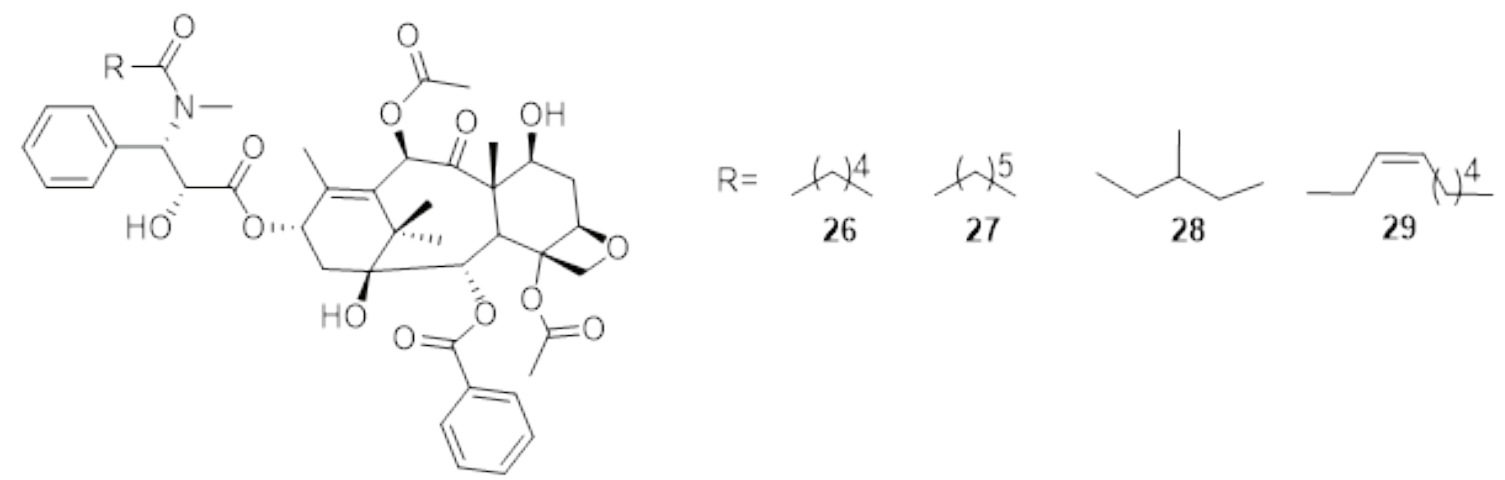

Figure 7 Structures of $N$-debenzoyl- $N$-methyl- $N$-heptanoyl-taxol[27], $N$-debenzoyl- $N$-methyl- $N$-octanoyl-taxol[28], $N$-debenzoyl- $N$ methyl- $N$-[4-methylhexanoyl]-axol[29], and $N$-debenzoyl- $N$-methyl- $N$-[[4Z]-1-oxo-4-tenenoyl]taxol[30]

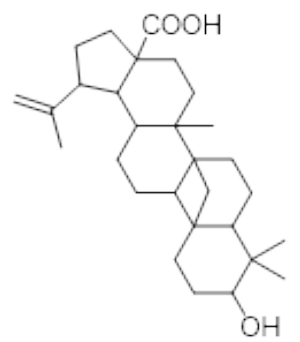

Figure 8 Structure of HOP-22(29)-EN-3

Strychnosnux-vomica might have an inhibitory potential against $\beta$-tubulin, but this has yet to be confirmed experimentally.

Stillingias anguinolenta is an endemic Mexican medical plant with many unusual cyclic organic compounds (67). About 30 Stillingia species are used as folk medicines for different purposes in America. In a recent study, Pfeffer et al. (68) reported inhibitory activity on kinesin-5 mitotic motor molecules by tonantzitlolone A(Figure 9, compound 30), a diterpene isolated from Stillingias anguinolenta, and by its synthetic enantiomer (compound 33). Both promote microtubule polymerisation by reducing the attachment of kinesin-5 molecules to microtubules, increasing, in turn, the growth rate and decreasing the mitotic catastrophe frequency. The synthetic enantiomer showed a stronger inhibitory effect than the natural compound $\left(\mathrm{IC}_{50} \sim 44.5 \mathrm{mmol} / \mathrm{L}\right.$ versus $\mathrm{IC}_{50} \sim 147 \mathrm{mmol} / \mathrm{L}$, respectively). This inhibitory effect is related to the chemical modification of the parent molecule responsible for the enhanced antiproliferative effect of the natural compound tonantzitlolone $\mathrm{A}$.

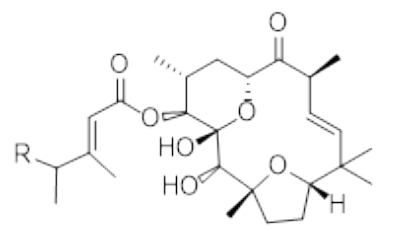

totantzitlolone A $30: \mathrm{R}=\mathrm{H}$ totantzitlolone B 31: R = OAC

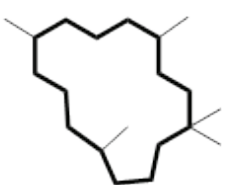

15-membered flexibilane backbone 32
Magnolol, a hydroxylated biphenyl compound, is isolated from Magnolia officinalis (Magnoliaceae). It has muscle relaxant, antioxidant, anti-atherosclerotic, antiinflammatory, and antimicrobial effects. It is widely used as a folk remedy, especially in the Far East (69). In recent years, it has been studied for anticancer effects (70-72) and reported to suppress metastasis in PC-3 human prostate carcinoma cells (70). Its wnt/beta-catenin signalling pathway has been shown to mediate anticancer effect (71). Magnolol has also been tested for cancer growth inhibition and shown to use the p53 pathway to suppress the development of cancer in gallbladder cancer cells (72). Shen et al. (73) tested its effect on cellular microtubule polymerisation in human non-small lung cancer cells. Its $\mathrm{IC}_{50}$ of approximately $5 \mu \mathrm{mol} / \mathrm{L}$ at $72 \mathrm{~h}$ makes it a promising candidate for the treatment of NSCLC.

Thalicthuberine, a phenanthrene alkaloid isolated from Hernandia albiflora (Hernandiaceae), is known for its antimicrobial activity (74). Levrier et al. (75) examined its antimitotic activity in prostate (PC-3) and cervical cancer (HeLa) cells and established respective $\mathrm{IC}_{50}$ of 0.7 and $2.5 \mathrm{mmol} / \mathrm{L}$. This promising agent did not directly inhibit tubulin polymerisation, but it destroyed cellular tubulin polymers and suppressed mitotic spindle dynamics.

$6 \alpha$-acetoxyanopterine (6-AA) is one of the anopterine analogues isolated from the Australian endemic tree Anopterus macleayanus. Levrier et al. (76) reported that 6-AA inhibited cell growth in prostate cell lines $\left(\mathrm{IC}_{50}=3.1-11.5 \mathrm{nmol} / \mathrm{L}\right)$. The same authors compared 6-AA activity with well-known microtubule inhibitors such as taxanes, vinca alkaloids, and 2-methoxyestradiol (2ME2) (Figure 10) to find a number of promising effects (77). At low, nanomolar, concentrations

Figure 9 Structures of tonantzitlolone A [30] and B [31], and schematic representation of the flexibilane backbone [32], [ent]tonantzitlolone A [33] 


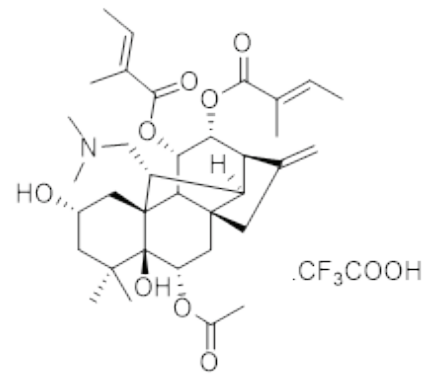

Figure 10 Structure of 2-methoxyestradiol (2ME2)

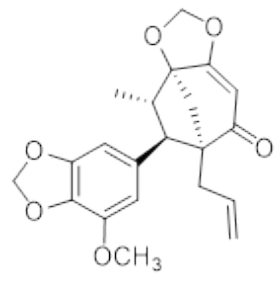

34

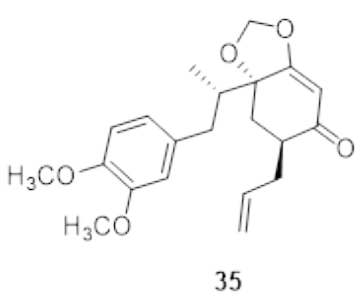

35
Figure 11 Structures of iso-ocobullenone [34] and bifidenone [35]

6-AA caused a strong accumulation of androgen-sensitive human prostate adenocarcinoma ( $\mathrm{LNCaP})$ cells in mitosis [through increased levels of phospho-Ser10 histone 3 protein (PHH3), which is a marker of mitosis], severe mitotic spindle defects, and asymmetric cell divisions in both prostate and cervical cancer cells. 6-AA caused mitotic catastrophe and cell death by apoptosis due to cell accumulation in the $\mathrm{G} 2 / \mathrm{M}$ phase and deregulation of mitotic pathways. It also turned out to be a reversible microtubuledestabilising molecule at nanomolar concentrations, which, unlike vinca alkaloids and 2ME2, directly interacted with tubulin.

Anticancer activity of polycyclic fatty acids contained in the plants of the genus Beilschmiedia has also been investigated. Williams et al. (78) collected plant materials in Nyanga (Gabon) and isolated one major component, neolignan iso-ocobullenone (Figure 11, compound 34), and a number of other minor components (Figure 11). Their cytotoxicity was screened with nuclear magnetic resonance (NMR) spectroscopy in NCI-H460 human lung cancer cells. Nine compounds had $\mathrm{IC}_{50}$ over $20 \mu \mathrm{g} / \mathrm{mL} ; 11$ between 20 and $1 \mu \mathrm{g} / \mathrm{mL}$, and only one, neolignan bifidenone (Figure 11 , compound 35 ), had the $\mathrm{IC}_{50}$ of $0.26 \mu \mathrm{mol} / \mathrm{L}$. It also showed high antiproliferative activity in other cancer cells, including melanoma cell lines (A375, UACC-62, and SKMel-2) and the first NCI-60-cell line ( $\mathrm{IC}_{50}$ of $0.27 \mu \mathrm{mol} / \mathrm{L}$ ), but not as high in the HCC-2998 colorectal cell line ( $\mathrm{IC}_{50}$ $1.41 \mu \mathrm{mol} / \mathrm{L})$. The most sensitive cell lines $\left(\mathrm{IC}_{50}<0.1 \mu \mathrm{mol} / \mathrm{L}\right)$ turned out to be SR lymphoblasts and the MALME-3M and MDA-MB-435 melanoma cells.

Mukhtar et al. (79) reported that compound 35 inhibited tubulin polymerisation in a dose-dependent manner, arrested the cell cycle in the G2/M phase, and competed for the colchicine binding site.

\section{ADVERSE EFFECTS OF MTAs}

\section{Haematological and gastrointestinal toxicity}

Haematological toxicities of MTAs are usually related to neutropenia and myelosuppression. Myelosuppression results from the inhibition of rapidly dividing hematopoietic cells. Neutropenia is a more serious and usually doselimiting factor (80).

\section{Neurological toxicity}

In addition to these adverse effects, clinical trials of a new epothilone class of MTAs (such as ixabepilone and sagopilone, analogous to taxanes) reported neurotoxicity, which diminished with lowering the dose, but this resulted in higher gastrointestinal toxicity (81).

A major limitation to the use of MTAs is the high rate of neuropathy. Microtubule integrity is critical to normal neuronal function, and any microtubule dysfunction can lead to the development of some form of neuropathy through disruption of axonal transport and function (82).

Peripheral neuropathy $(\mathrm{PN})$ is a result of damage to peripheral nerves. It is a prominent dose-limiting adverse effect of paclitaxel (83). This drug induces microtubule aggregation in the peripheral nervous system and interrupts axonal transport. Severe PN is less common in patients treated with docetaxel. However, there is no reliable objective method to assess PN, and PN diagnosis relies on clinical assessment, including physical examination (84).

\section{CHALLENGES}

Although many MSAs have been applied extensively in clinical settings, the use of paclitaxel and other approved MSAs still presents many challenges, such a slow passage through the blood-brain barrier (BBB), poor solubility, toxicity, multidrug resistance, and low bioavailability. To overcome these challenges, many studies have focused on the structure-activity relationships. Investigations have improved some pharmaceutical properties of MTAs without significant problems (85).

The main purpose of effective cancer treatment is to improve the specificity of therapy and to reduce adverse effects, especially those limiting the dose. For example, CA-4 monotherapy has raised doubts due to metabolic vulnerability and conformational instability (86). It is important to reduce MTA toxicities against rapidly proliferating healthy cell compartments, such as haematological and gastrointestinal tissues.

Drug resistance is another major limitation. New targeted therapies and treatment approaches are being developed to overcome these limitations, including monoclonal antibodies (e. g. trastuzumab, bevacizumab), small molecule therapies (e. g. tyrosine kinase inhibitors, bortezomib), and drug conjugates. An example of the last 
group is vintafolide (EC 145), a water-soluble derivative of folic acid currently under evaluation in phase II clinical trials for the treatment of ovarian and lung cancer. It targets the upregulation of folate receptor (FR) expression. Folate receptors take three principal isoforms $(\alpha, \beta$, and $\gamma)$ with high affinity for folate-binding glycoproteins. FR $\alpha$ and FR $\beta$ strongly bind folic acid and its major circulating form 5-methyltetrahydrofolate (MeTHF). FR $\alpha$ is expressed at very high levels in ovarian, lung, kidney, and breast cancer, and its expression is a negative prognostic factor in patients with ovarian, breast, endometrial, uterine, and colorectal cancer (83).

\section{CURRENT CLINICAL TRIALS}

Many new generation MTAs are still under evaluation for potential clinical use. Some of them have shown good tolerability and antitumor activity in specific cancers. ClinicalTrials.gov, a web-based resource established by the National Library of Medicine (NLM) of the National Institutes of Health (NIH), registered 5,662 ongoing and completed trials for various cancer treatments in 2018 (Figure 12) (87).

Even though vinca alkaloids and taxanes have been known for 50 years, the scarcity of their natural sources (such as Pacific yew bark for taxol) is now being overcome by partial or total synthesis. However, total synthesis is still not the best option for development of drugs used in clinics. This situation is prevalent for many of the novel microtubule binding agents $(88,89)$. Tubulin inhibitors are generally used in combination with other chemotherapeutic drugs. Paclitaxel is commonly used with gemcitabine for the treatment of metastatic adenocarcinoma of the pancreas, while cabazitaxel is used with prednisone for the treatment of metastatic, hormone-resistant prostate cancer.

\section{SCREENING SYSTEMS FOR MTAs}

Screening systems, such as phenotypic screening and Biological Similarity Ensemble Approach (BIOSEA), screen large libraries of chemical compounds to help drug industry develop effective and safe drugs through new approaches that would bring some advantage over the currently available methods used in drug research and development.

\section{Phenotypic screening}

Phenotypic screening is used in drug discovery to identify molecules (in animal models or cell-based assays) that can alter cell phenotype. It does not rely on knowing specific drug target or its hypothetical role in the disease. This type of screening can capture complex biological mechanisms that escape other approaches. It provides the understanding of cell signalling networks in disease development and decreases the amount of clinical trial failures by identifying factors contributing to unexpected activity, toxicities, and lack of efficacy.

The enthusiasm for phenotypic screening as an alternative to target-focused small-molecule discovery has increased dramatically over the last few years. Phenotypic screening is based on the results of animal, cell-based, and disease-related phenotypic assays, which determine the phenotype of a physiological system. It also includes all preclinical assay formats that use animals, cells, and biochemical pathways. The aim is to identify molecules with specific biological effects that alter microtubule stability (90). Between 1999 and 2013; phenotypic screening has resulted in the discovery of 48 cancer drugs approved by the FDA, including three tubulin inhibitors (Table 1).

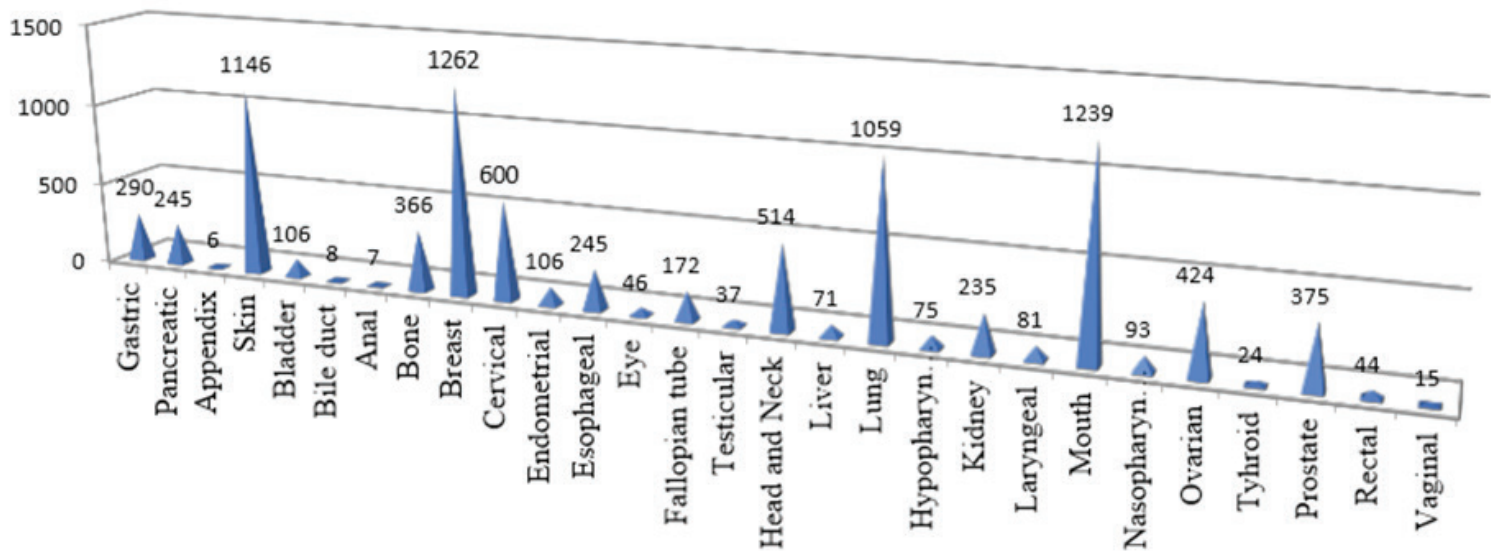

Figure 12 Distribution of cancer types treated with MTAs in clinical trials [available from ClinicalTrials.gov (104)] 


\section{Biological Similarity Ensemble Approach}

Cortes Cabrera et al. (91) developed a statistical method called Biological Similarity Ensemble Approach (BIOSEA) to streamline the phenotypic screening workflow. This statistical method identifies molecules able to reproduce a desired cellular phenotype based on biological similarity with compounds with such effect. This method provided an advantage over high-throughput screening assays and overcame problems such as highly incomplete and noisy compound bioactivity. It helped identify novel nanomolar inhibitors of cell division that reproduce the action of reference natural products.

The last two decades have seen a dramatic change in the understanding of interactions between small molecules and biological systems. It came with a major shift from reductionism to a more pragmatic view of living organisms as complex entities. At the same time phenotypic screening brought new challenges, such as the identification of mechanisms of action and effective targets responsible for these phenotypes. BIOSEA allows phenotypic screening without the need for information about the chemical structure of the target or associated ligands. One example is the Na-K-Cl cotransporter (NKCC1) (91). Its cellular phenotype was characterised, and well-known natural products that inhibit cell division in two different ways, namely paclitaxel as a microtubule-stabilising agent and one tubulin polymerisation inhibitor, were selected as references to predict biologically similar compounds that could arrest the cell cycle.

In short, this statistical method establishes new relationships between targets and small molecules, which streamlines drug discovery.

\section{CONCLUSION}

Continuing research on the mechanisms of action of MTAs, discovery of new drugs, and search for novel therapy strategies helps to reduce their adverse effects, overcome resistance to cancer therapy, and provide more effective therapeutic options for cancer patients. This cannot be achieved without a better understanding of the molecular mechanisms of microtubule-dependent, tumour-specific pathways.

\section{Conflicts of interest}

None to declare.

\section{REFERENCES}

1. Chabner BA, Roberts TG Jr. Timeline: Chemotherapy and the war on cancer. Nat Rev Cancer 2005;5:65-72. doi: $10.1038 / \mathrm{nrc} 1529$

2. World Health Organization (WHO). Cancer, Fact sheet February 2017 [displayed 9 September 2019]. Available at https://www.who.int/news-room/fact-sheets/detail/cancer

3. Kumar S, Ahmad MK, Waseem M, Pandey AK. Drug targets for cancer treatment: an overview. Med Chem 2015;5:11523. doi: 10.4172/2161-0444.1000252

4. Poruchynsky MS, Komlodi-Pasztor E, Trostel S, Wilkerson J, Regairaz M, Pommier Y, Zhang X, Kumar Maity T, Robey R, Burotto M, Sackett D, Guha U, Fojo AT. Microtubuletargeting agents augment the toxicity of DNA-damaging agents by disrupting intracellular trafficking of DNA repair proteins. Proc Natl AcadSci U S A 2015;112:1571-6. doi: 10.1073/pnas.1416418112

5. Giavazzi R, Bonezzi K, Taraboletti G. Microtubule targeting agents and the tumor vasculature. In: Fojo AT, editor. The role of microtubules in cell biology, neurobiology, and oncology. Totowa (NJ). Humana Press; 2008. p. 519-30.

6. Jordan MA, Wilson L. Microtubules as a target for anticancer drugs. Nat Rev Cancer 2004;4:253-65. doi: 10.1038/nrc1317

7. Dong M, Liu F, Zhou H, Zhai S, Yan B. Novel natural product and privileged scaffold-based tubulin inhibitors targeting the colchicine binding site. Molecules 2016;21:1375. doi: $10.3390 /$ molecules 21101375

Table 1 Details of cancer drugs approved by the FDA between 1999 and 2013 [adapted from Moffat et al. (90)]

\begin{tabular}{|c|c|c|c|c|c|c|}
\hline Drug & $\begin{array}{l}\text { Approved } \\
\text { Year }\end{array}$ & $\begin{array}{c}\text { Target } \\
\text { discovery }\end{array}$ & $\begin{array}{l}\text { Candidate } \\
\text { selection }\end{array}$ & $\begin{array}{c}\text { Target } \\
\mathbf{T} / \mathbf{M}\end{array}$ & $\begin{array}{c}\text { Molecular } \\
\text { MOA }\end{array}$ & Comments \\
\hline Cabazitaxel & 2010 & $\begin{array}{l}\text { Mechanism- } \\
\text { informed } \\
\text { phenotypic } \\
\text { drug } \\
\text { discovery }\end{array}$ & $\begin{array}{l}\text { Mechanism- } \\
\text { informed } \\
\text { phenotypic } \\
\text { drug discovery }\end{array}$ & $\mathrm{T}$ & $\begin{array}{c}\text { Microtubule } \\
\text { stabiliser }\end{array}$ & $\begin{array}{l}\text { Taxane analogue selected } \\
\text { for low P glycoprotein } \\
\text { affinity or efflux }\end{array}$ \\
\hline Eribulin & 2010 & Phenotypic & $\begin{array}{l}\text { Mechanism- } \\
\text { informed } \\
\text { phenotypic } \\
\text { drug discovery }\end{array}$ & M & $\begin{array}{l}\text { Microtubule } \\
\text { stabiliser }\end{array}$ & $\begin{array}{l}\text { Synthetic analogue of } \\
\text { natural product from } \\
\text { cytotoxicity screen; } \\
\text { optimised by antimitotic } \\
\text { activity }\end{array}$ \\
\hline Ixabepilone & 2007 & $\begin{array}{l}\text { Mechanism- } \\
\text { informed } \\
\text { phenotypic } \\
\text { drug } \\
\text { discovery }\end{array}$ & Targeted & M & $\begin{array}{l}\text { Microtubule } \\
\text { stabiliser }\end{array}$ & $\begin{array}{c}\text { Rationally designed } \\
\text { epothilone analogue; } \\
\text { parent drug discovered } \\
\text { by phenotypic cytotoxic } \\
\text { screening. }\end{array}$ \\
\hline
\end{tabular}


8. Kavallaris M, Kuo DY, Burkhart CA, Regl DL, Norris MD, Haber M, Horwitz SB. Taxol-resistant epithelial ovarian tumors are associated with altered expression of specific beta-tubulin isotypes. J Clin Invest 1997;100:1282-93. doi: 10.1172/JCI119642

9. Forli S. Epothilones: from discovery to clinical trials. Curr Top Med Chem 2014;14:2312-21. doi: 10.2174/156802661 4666141130095855

10. Crimmins MT. Synthetic approaches to the microtubule stabilizing agent (-)-laulimalide. Curr Opin Drug Discoy Devel 2002;5:944-59. PMID: 12478725

11. Steinmetz MO, Prota AE. Microtubule-targeting agents: strategies to hijack the cytoskeleton. Trends Cell Biol 2018;28:776-92. doi: 10.1016/j.tcb.2018.05.001

12. Sapra S, Bhalla Y, Sharma S, Singh G, Nepali K, Budhiraja A, Dhar KL. Colchicine and its various physicochemical and biological aspects. Med Chem Res 2013;22:531-47. doi 10.1007/s00044-012-0077-z

13. Jain S, Vahdat LT. Eribulinmesylate. Clin Cancer Res 2011;17:6615-22. doi: 10.1158/1078-0432.CCR-11-1807

14. Modrianský M, Dvorák Z. Microtubule disruptors and their interaction with biotransformation enzymes. Biomed Pap Med Fac Univ Palacky Olomouc Czech Repub 2005; 149:2135. doi: $10.5507 / \mathrm{bp} .2005 .028$

15. Dumontet C, Jordan MA. Microtubule-binding agents: a dynamic field of cancer therapeutics. Nat Rev Drug Discov 2010;9:790-803. doi: 10.1038/nrd3253

16. Prota AE, Bargsten K, Zurwerra D, Field JJ, Díaz JF, Altmann $\mathrm{KH}$, Steinmetz MO. Molecular mechanism of action of microtubule-stabilizing anticancer agents. Science 2013;339:587-90. doi: 10.1126/science.1230582

17. Pryor DE, O’Brate A, Bilcer G, Díaz JF, Wang Y, Wang Y, Kabaki M, Jung MK, Andreu JM, Ghosh AK, Giannakakou P, Hamel E. The microtubule stabilizing agent laulimalide does not bind in the taxoid site, kills cells resistant to paclitaxel and epothilones, and may not require its epoxide moiety for activity. Biochemistry 2002;41:9109-15. doi: 10.1021/bi020211b

18. Prota AE, Bargsten K, Northcote PT, Marsh M, Altmann KH, Miller JH, Díaz JF, Steinmetz MO. Structural basis of microtubule stabilization by laulimalide and peloruside A. Angew Chem Int Ed Engl 2014;53:1621-5. doi: 10.1002/ anie. 201307749

19. Pellegrini F. Review: Tubulin function, action of antitubulin drugs and new drug development. Cancer Invest 2005;23:264 73. doi: $10.1081 / \mathrm{CNV}-200055970$

20. Ley CD, Horsman MR, Kristjansen PE. Early effects of combretastatin-A4 disodium phosphate on tumor perfusion and interstitial fluid pressure. Neoplasia 2007;9:108-12. doi: 10.1593/neo.06733

21. Gutiérrez ST, Díaz-Oltra S, Falomir E, Murga J, Cardaa M, Marco JA. Synthesis of combretastatin A-4 O-alkyl derivatives and evaluation of their cytotoxic, antiangiogenic and antitelomerase activity. Bioorg Med Chem 2013;21:726774. doi: 10.1016/j.bmc.2013.09.064

22. Ohsumi K, Hatanaka T, Fujita K, Nakagawa R, Fukuda Y, Nihei Y, Suga Y, Morinaga Y, Akiyama Y, Tsuji T. Syntheses and antitumor activity of cis-restricted combretastatins, 5 -membered heterocyclic analogues. Bioorg Med Chem Lett 1998;8:3153-8. doi: 10.1016/s0960-894x(98)00579-4

23. Yang T, Wang Y, Li Z, Dai W, Yin J, Liang L, Ying X, Zhou S, Wang J, Zhang X, Zhang Q. Targeted delivery of a combination therapy consisting of combretastatin A4 and low-dose doxorubicin against tumorneovasculature. Nanomedicine 2012;8:81-92. doi: 10.1016/j. nano.2011.05.003

24. Gao M, Zhang D, Jin Q, Jiang C, Wang C, Li J, Peng F, Huang D, Zhang J, Song S. Combretastatin-A4 phosphate improves the distribution and antitumor efficacy of albumin-bound paclitaxel in W256 breast carcinoma model. Oncotarget 2016;7:58133-41. doi: 10.18632/oncotarget.11249

25. Abma E, Daminet S, Smets P, Ni Y, de Rooster H. Combretastatin A4-phosphate and its potential in veterinary oncology, a review. Vet Comp Oncol 2017;15:184-93. doi: $10.1111 /$ vco. 12150

26. Marzo-Mas A, Barbier P, Breuzard G, Allegro D, Falomir E, Murga J, Carda M, Peyrot V, Marco JA. Interactions of longchain homologues of colchicine with tubulin. Eur J Med Chem 2017;126:526-35. doi: 10.1016/j.ejmech.2016.11.049

27. Ahmed RI, Osman EE, Awadallah FM, El-Moghazy SM. Design, synthesis and molecular docking of novel diarylcyclohexenone and diarylindazole derivatives as tubulin polymerization inhibitors. J Enzyme Inhib Med Chem 2017;32:176-88. doi: 10.1080/14756366.2016.1244532

28. De Martino G, La Regina G, Coluccia A, Edler MC, Barbera MC, Brancale A, Wilcox E, Hamel E, Artico M, Silvestri R. Arylthioindoles, potent inhibitors of tubulin polymerization. J Med Chem 2004;47:6120-3. doi: 10.1021/jm049360d

29. Tantak MP, Wang J, Singh RP, Kumar A, Shah K, Kumar D. 2-(3'-Indolyl)-N-arylthiazole-4-carboxamides: Synthesis and evaluation of antibacterial and anticancer activities. Bioorg Med Chem Lett 2015;25:4225-31. doi: 10.1016/j. bmcl.2015.07.105

30. Kamath PR, Sunil D, Ajees AA, Pai KS, Das S. Some new indole-coumarin hybrids; Synthesis, anticancer and Bcl-2 docking studies. Bioorg Chem 2015;63:101-9. doi: 10.1016/j.bioorg.2015.10.001

31. Das Mukherjee D, Kumar NM, Tantak MP, Das A, Ganguli A, Datta S, Kumar D, Chakrabarti G. Development of novel bis(indolyl)-hydrazide-hydrazone derivatives as potent microtubule-targeting cytotoxic agents against A549 lung cancer cells. Biochemistry 2016;55:3020-35. doi: 10.1021/ acs.biochem.5b01127

32. Liu Y-M, Chen H-L, Lee H-Y, Liou J-P. Tubulin inhibitors: a patent review. Expert OpinTher Pat 2014;24:69-88. doi: $10.1517 / 13543776.2014 .859247$

33. Ramya PVS, Guntuku L, Angapelly S, Digwal CS, Lakshmi UJ, Sigalapalli DK, Babu BN, Naidu VGM, Kamal A. Synthesis and biological evaluation of curcumin inspired indole analogues as tubulin polymerization inhibitors. Eur J Med Chem 2017;127:100-14. doi: 10.1016/j. ejmech.2016.12.043

34. Zhang YL, Qin YJ, Tang DJ, Yang MR, Li BY, Wang YT, Cai HY, Wang BZ, Zhu HL. Synthesis and biological evaluation of 1-methyl-1H-indole-pyrazoline hybrids as potential tubulin polymerization inhibitors. Chem Med Chem 2016;11:1446-58. doi: 10.1002/cmdc.201600137

35. Wang YT, Cai XC, Shi TQ, Zhang YL, Wang ZC, Liu CH, Zhu HL. Synthesis, molecular docking and biological evaluation of 1-phenylsulphonyl-2-(1-methylindol-3-yl)benzimidazole derivatives as novel potential tubulin assembling inhibitors. Chem Biol Drug Des 2017;90:112-8. doi: 10.1111/cbdd.12932 
36. Guggilapu SD, Lalita G, Reddy TS, Prajapti SK, Nagarsenkar A, Ramu S, Brahma UR, Lakshmi UJ, Vegi GMN, Bhargava SK, Babu BN. Synthesis of C5-tethered indolyl-3glyoxylamide derivatives as tubulin polymerization inhibitors. Eur J Med Chem 2017;28:1-12. doi: 10.1016/j. ejmech.2017.01.026

37. Chennamaneni S, Gan C, Lama R, Zhong B, Su B Indomethacin derivatives as tubulin stabilizers to inhibit cancer cell proliferation. Bioorg Med Chem 2016;24:277-85. doi: 10.1016/j.bmc.2015.12.016

38. Baytas SN, Inceler N, Yilmaz A, Olgac A, Menevse S, Banoglu E, Hamel E, Bortolozzi R, Viola G. Synthesis, biological evaluation and molecular docking studies of transindole-3-acrylamide derivatives, a new class of tubulin polymerization inhibitors. Bioorg Med Chem 2014;22:3096104. doi: 10.1016/j.bmc.2014.04.027

39. Ghinet A, Moise IM, Rigo B, Homerin G, Farce A, Dubois J, Bîcu E. Studies on phenothiazines, new microtubuleinteracting compounds with phenothiazine A-ring as potent antineoplastic agents. Bioorg Med Chem 2016;24:2307-17. doi: 10.1016/j.bmc.2016.04.001

40. Ali I, Lone MN, Al-Othman ZA, Al-Warthan A, Sanagi MM. Heterocyclic scaffolds: centrality in anticancer drug development. Curr Drug Targets 2015;16:711-34. doi: 10.2 174/1389450116666150309115922

41. Singh S, Ahmad A, Raghuvanshi DS, Hasanain M, Agarwal K, Dubey V, Fatima K, Alam S, Sarkar J, Luqman S, Khan F, Tandon S, Gupta A. Synthesis of 3,5-dihydroxy-7,8dimethoxy-2-(4-methoxyphenyl)benzopyran-4-one derivatives as anticancer agents. Bioorg Med Chem Lett 2016;26:5322-7. doi: 10.1016/j.bmcl.2016.09.036

42. Andújar I, Ríos JL, Giner RM, Recio MC. Pharmacological properties of shikonin - a review of literature since 2002. Planta Med 2013;79:1685-97. doi: 10.1055/s-0033-1350934

43. Andújar I, Ríos JL, Giner RM, Recio MC. Shikonin promotes intestinal wound healing in vitro via induction of TGF- $\beta$ release in IEC-18 cells. Eur J Pharm Sci 2013;49:637-41. doi: 10.1016/j.ejps.2013.05.018

44. Huang CS, Lin AH, Yang TC, Liu KL, Chen HW, Lii CK. Shikonin inhibits oxidized LDL-induced monocyte adhesion by suppressing NFKB activation via up-regulation of PI3K/ Akt/Nrf2-dependent antioxidation in EA.hy926 endothelial cells. Biochem Pharmacol 2015;93:352-61. doi: 10.1016/j. bcp.2014.12.005

45. Skrzypczak A, Przystupa N, Zgadzaj A, Parzonko A, Sykłowska-Baranek K, Paradowska K, Nałęcz-Jawecki G. Antigenotoxic, anti-photogenotoxic and antioxidant activities of natural naphthoquinone shikonin and acetylshikonin and Arnebiaeuchroma callus extracts evaluated by the umu-test and EPR method. Toxicol In Vitro 2015;30:364-72. doi: 10.1016/j.tiv.2015.09.029

46. Liang D, Sun Y, Shen Y, Li F, Song X, Zhou E, Zhao F, Liu Z, Fu Y, Guo M, Zhang N, Yang Z, Cao Y. Shikonin exerts anti-inflammatory effects in a murine model of lipopolysaccharide-induced acute lung injury by inhibiting the nuclear factor-kappa B signaling pathway. IntImmunopharmacol 2013;16:475-80. doi: 10.1016/j. intimp. 2013

47. Liu J, Wang P, Xue YX, Li Z, Qu CB, Liu YH. Enhanced antitumor effect of shikonin by inhibiting Endoplasmic Reticulum Stress via JNK/c-Jun pathway in human glioblastoma stem cells. Biochem Biophys Res Commun 2015;466:103-10. doi: 10.1016/j.bbrc.2015.08.115

48. Qiu HY, Wang F, Wang X, Sun WX, Qi JL, Pang YJ, Yang RW, Lu GH, Wang XM, Yang YH. Design, synthesis, and biological evaluation of chalcone-containing shikonin derivatives as inhibitors of tubulin polymerization. Chem Med Chem 2017;12:399-406. doi: 10.1002/cmdc.201700001

49. Kamal A, Srikanth YV, Naseer Ahmed Khan M, Ashraf M, Kashi Reddy M, Sultana F, Kaur T, Chashoo G, Suri N, Sehar I, Wani ZA, Saxena A, Sharma PR, Bhushan S, Mondhe DM, Saxena AK. 2-Anilinonicotinyl linked 2-aminobenzothiazoles and $[1,2,4]$ triazolo[ $[1,5-b][1,2,4]$ benzothiadiazine conjugates as potential mitochondrial apoptotic inducers. Bioorg Med Chem 2011;19:7136-50. doi: 10.1016/j.bmc.2011.09.060

50. Kamal A, Hussaini SM, Nayak VL, Malik MS, Sucharitha ML, Shaik TB, Ashraf M, Bagul C. Synthesis of 2-anilinopyridine dimers as microtubule targeting and apoptosis inducing agents. Bioorg Med Chem 2014;22:675567. doi: 10.1016/j.bmc.2014.11.001

51. Kamal A, Khan MN, Srinivasa Reddy K, Rohini K. Synthesis of a new class of 2-anilino substituted nicotinylarylsulfonylhydrazides as potential anticancer and antibacterial agents. Bioorg Med Chem 2007;15:1004-13. doi: 10.1016/j.bmc.2006.10.027

52. Dorléans A, Gigant B, Ravelli RB, Mailliet P, Mikol V, Knossow $M$. Variations in the colchicine-binding domain provide insight into the structural switch of tubulin. Proc Natl Acad Sci USA 2009;106:13775-9. doi: 10.1073/ pnas.0904223106

53. Elmeligie S, Khalil NA, Ahmed EM, Emam SH. New 3-substituted-2-(4-hydroxyanilino) pyridine derivatives, synthesis, antitumor activity and tubulin polymerization inhibition. Arch Pharm (Weinheim) 2017;350(2):e1600256. doi: $10.1002 / \operatorname{ardp} .201600256$

54. Liu YN, Wang JJ, Ji YT, Zhao GD, Tang LQ, Zhang CM, Guo XL, Liu ZP. Design, synthesis and biological evaluation of 1 methyl-1,4-dihydroindeno[1,2-c]pyrazole analogues as potential anticancer agents targeting tubulin colchicine binding site. J Med Chem 2016;59:5341-55. doi: 10.1021/ acs.jmedchem.6b00071

55. Ali I, Haque A, Saleem K, Hsieh MF. Curcumin-I Knoevenagel's condensates and their Schiff's bases as anticancer agents: synthesis, pharmacological and simulation studies. Bioorg Med Chem 2013;21:3808-20. doi: 10.1016/j. bmc.2013.04.018

56. Saleem K1, Wani WA, Haque A, Lone MN, Hsieh MF, Jairajpuri MA, Ali I. Synthesis, DNA binding, hemolysis assays and anticancer studies of copper(II), nickel(II) and iron(III) complexes of a pyrazoline-based ligand. Future Med Chem 2013;5:135-46. doi: 10.4155/fmc.12.201

57. Magalhaes LG, Marques FB, da Fonseca MB, Rogério KR, Graebin CS, Andricopulo AD. Discovery of a series of acridinones as mechanism-based tubulin assembly inhibitors with anticancer activity. Plos One 2016;11(8):e0160842. doi: 10.1371/journal.pone. 0160842

58. Devambatla RK, Namjoshi OA, Choudhary S, Hamel E, Shaffer CV, Rohena CC, Mooberry SL, Gangjee A. Design, synthesis, and preclinical evaluation of 4 substituted-5methyl-furo[2,3- $d]$ pyrimidines as microtubule targeting agents that are effective against multidrug resistant cancer cells. J Med Chem 2016;59:5752-65. doi: 10.1021/acs. jmedchem.6b00237 
59. Mollinedo F, Gajate C. Microtubules, microtubule-interfering agents and apoptosis. Apoptosis 2003;8:413-50. doi: 10.1023/A:1025513106330

60. Zhou J, Giannakakou P. Targeting microtubules for cancer chemotherapy. Curr Med Chem Anticancer Agents 2005;5:65-71. doi: 10.2174/1568011053352569

61. Schiff PB, Fant J, Horwitz SB. Promotion of microtubule assembly in vitro by taxol. Nature 1979;277:665-7. doi: 10.1016/j.ab.2006.10.014

62. Buey RM, Barasoain I, Jackson E, Meyer A, Giannakakou P, Paterson I, Mooberry S, Andreu JM, Díaz JF. Microtubule interactions with chemically diverse stabilizing agents, thermodynamics of binding to the paclitaxel site predicts cytotoxicity. Chem Biol 2005;12:1269-79. doi: 10.1016/j. chembiol.2005.09.010

63. Kingston DGI, Jagtap PG, Yuan H, Samala L. The chemistry of taxol and related taxoids. In: Herz W, Falk H, Kirby GW, editors. Progress in the chemistry of organic natural products. Vol. 84. Wien: Springer; 2002. p. 53-225.

64. Wang Y, Wang J, Wang H, Ye W. Novel taxane derivatives from Taxus wallichiana with high anticancer potency on tumor cells. Chem Biol Drug Des 2016;88:556-61. doi: 10.1111/cbdd. 12782

65. Barbier P, Tsvetkov PO, Breuzard G, Devred F. Deciphering the molecular mechanisms of anti-tubulin plant derived drugs. Phytochem Rev 2014;13:157-69. doi: 10.1007/ s11101-013-9302-8

66. Verma K, Kannan K, Shanthi V, Sethumadhavan R, Karthick V, Ramanathan K. Exploring $\beta$-tubulin inhibitors from plant origin using computational approach. Phytochem Anal 2017;28:230-41. doi: 10.1002/pca.2665

67. Busch T, Kirschning A. Recent advances in the total synthesis of pharmaceutically relevant diterpenes. Nat Prod Rep 2008;25:318-41. doi: 10.1039/b705652b

68. Pfeffer TJ, Sasse F, Schmidt CF, Lakämper S, Kirschning A, Scholz T. The natural diterpenetonantzitlolone A its synthetic enantiomer inhibits cell proliferation and kinesin-5 function. Eur J Med Chem 2016;112:164-70. doi: 10.1016/j. ejmech.2016.02.022

69. Lee YJ, Lee YM, Lee CK, Jung JK, Han SB, Hong JT. Therapeutic applications of compounds in the Magnolia family. Pharmacol Ther 2011;130:157-76. doi: 10.1016/j. pharmthera.2011.01.010

70. Hwang ES, Park KK. Magnolol suppresses metastasis via inhibition of invasion, migration, and matrix metalloproteinase-2/-9 activities in PC-3 human prostate carcinoma cells. Biosci Biotechnol Biochem 2010;74:961-7. doi: $10.1271 / \mathrm{bbb} .90785$

71. Kang YJ, Park HJ, Chung HJ, Min HY, Park EJ, Lee MA, Shin Y, Lee SK. Wnt/ $\beta$-catenin signaling mediates the antitumor activity of magnolol in colorectal cancer cells. Mol Pharmacol 2012;82:168-77. doi: 10.1124/mol.112.078535

72. Li ML, Zhang F, Wang XA, Wu XS, Zhang BT, Zhang N, Wu WG, Wang Z, Weng H, Liu SB, Gao GF, Mu JS, Shu YJ, Bao RF, Cao Y, Lu JH, Gu J, Zhu J, Liu YB. Magnolol inhibits growth of gallbladder cancer cells through the p53 pathway. Cancer Sci 2015;106:1341-50. doi: 10.1111/cas.12762

73. Shen J, Ma H, Zhang T, Liu H, Yu L, Li G, Li H, Hu M. Magnolol inhibits the growth of non-small cell lung cancer via inhibiting microtubule polymerization. Cell Physiol Biochem 2017;42:1789-801. doi: 10.1159/000479458
74. Wu W-N, Beal JL, Doskotch RW. Alkaloids of thalictrum XXX. Eleven minor alkaloids from Thalictrum rugosum. J Nat Prod 1980;43:143-50. doi: 10.1021/np50007a014

75. Levrier C, Rockstroh A, Gabrielli B, Kavallaris M, Lehman M, Davis RA, Sadowski MC, Nelson CC. Discovery of thalicthuberine as a novel antimitotic agent from nature that disrupts microtubule dynamics and induces apoptosis in prostate cancer cells. Cell Cycle 2018;17:652-68. doi: 10.1080/15384101.2017.1356512

76. Levrier C, Sadowski MC, Nelson CC, Davis RA. Cytotoxic $\mathrm{C}_{20}$ diterpenoid alkaloids from the Australian endemic rainforest plant Anopterusmacleayanus. J Nat Prod 2015;78:2908-16. doi: 10.1021/acs.jnatprod.5b00509

77. Levrier C, Sadowski MC, Rockstroh A, Gabrielli B, Kavallaris M, Lehman M, Davis RA, Nelson CC. $6 \alpha$-acetoxyanopterine, a novel structure class of mitotic inhibitor disrupting microtubule dynamics in prostate cancer cells. Mol Cancer Ther 2017;16:3-15. doi: 10.1158/15357163.MCT-16-0325

78. Williams RB, Martin SM, Lawrence JA, Norman VL, O'NeilJohnson M, Eldridge GR, Starks CM. Isolation and identification of the novel tubulin polymerization inhibitor bifidenone. J Nat Prod 2017;80:616-24. doi: 10.1021/acs. jnatprod.6b00893

79. Mukhtar E, Mustafa Adhami V, Mukhtar H. Targeting microtubules by natural agents for cancer therapy. Mol Cancer Ther 2014;13:275-84. doi: 10.1158/1535-7163.MCT13-0791

80. Soto E, Keizer RJ, Trocóniz IF, Huitema AD, Beijnen JH, Schellens JH, Wanders J, Cendrós JM, Obach R, Peraire C, Friberg LE, Karlsson MO. Predictive ability of a semimechanistic model for neutropenia in the development of novel anti-cancer agents: two case studies. Invest New Drugs 2011;29:984-95. doi: 10.1007/s10637-010-9437-z

81. Cheng KL, Bradley T, Budman DR. Novel microtubuletargeting agents - the epothilones. Biologics 2008;2:789-811. PMCID: PMC2727900

82. Baas PW, Ahmad FJ. Beyond taxol: microtubule-based treatment of disease and injury of the nervous system. Brain 2013;136:2937-51. doi: 10.1093/brain/awt153

83. Rowinsky EK, Donehower RC. Paclitaxel (taxol). N Engl J Med 1995;332:1004-14. doi: 10.1056/ NEJM199504133321507

84. Lee JJ, Swain SM. Peripheral neuropathy induced by microtubule-stabilizing agents. J Clin Oncol 2006;24:163342. doi: $10.1200 / \mathrm{JCO} .2005 .04 .0543$

85. Ying Z, Xin M, Guanhua D. Microtubule-stabilizing agents: New drug discovery and cancer therapy. Pharmacol Therap 2016;162:134-43. doi: 10.1016/j.pharmthera.2015.12.006

86. Tarade D, Pandey S, McNulty J. Review of cytotoxic CA4 analogues that do not target microtubules, implications for CA4 development. Mini Rev Med Chem 2017;17:1507-14. doi: 10.2174/1389557515666160509125829

87. US National Library of Medicine (NLM). ClinicalTrials.gov [displayed 10 September 2019]. Available at https:// clinicaltrials.gov/ct2/results?term=tubulin+inhibitors

88. de Lemos E, Porée FH, Bourin A, Barbion J, Agouridas E, Lannou MI, Commerçon A, Betzer JF, Pancrazi A, Ardisson J. Total synthesis of discodermolide, optimization of the effective synthetic route. Chemistry 2008;14:11092-112. doi: 10.1002/chem.200801478 
89. Wender PA, Hegde SG, Hubbard RD, Zhang L. Total synthesis of (-)-laulimalide. J Am Chem Soc 2002;124:49567. doi: $10.1021 / \mathrm{ja} 0258428$

90. Moffat JG, Rudolph J, Bailey D. Phenotypic screening in cancer drug discovery - past, present and future. Nat Rev Drug Discov 2014;13:588-602. doi: 10.1038/nrd4366
91. Cortes Cabrera A, Lucena-Agell D, Redondo-Horcajo M, Barasoain I, Díaz JF, Fasching B, Petrone PM. Aggregated compound biological signatures facilitate phenotypic drug discovery and target elucidation. ACS Chem Biol 2016;11:3024-34. doi: 10.1021/acschembio.6b00358

\section{Pregled lijekova protiv raka koji ciljano djeluju na mikrotubule}

U cijelome se svijetu traga za djelotvornim liječenjem protiv raka čije bi koristi prevagnule nad štetnim djelovanjem. Jedan od načina da se smanji otpornost na kemoterapiju i njezine štetne učinke svakako je takozvano ciljano liječenje, usmjereno na pojedine molekule (molekulske ciljeve) koje imaju važnu ulogu u rastu, napredovanju i metastaziranju raka. Primjer takvih specifičnih ciljeva su mikrotubuli. U ovom se preglednom radu osvrćemo na najnovije spoznaje o lijekovima koji ciljano djeluju na mikrotubule (engl. microtubule-targeting agents/drugs, krat. MTA/MTD), a rabe se u liječenju raka. Takvi prirodni i sintetizirani lijekovi djeluju protutumorski, a pretklinička istraživanja i klinička ispitivanja pokazuju da je njihova djelotvornost veća nego ona tradicionalnih lijekova. Osim toga, ti lijekovi donose manji rizik od štetnih učinaka poput neurotoksičnosti i hemotoksičnosti. Upravo se klinički ocjenjuju nove generacije nekoliko lijekova koji ciljano djeluju na mikrotubule. Ovdje donosimo najnovije spoznaje o njihovim koristima, pristupima liječenju, prednostima $\mathrm{i}$ izazovima u istraživanju. 